\title{
The Role of Training and Development to Improve Staff Performance : A Phenomenological Approach of Government Institutions in Jakarta
}

\author{
Pryo Handoko \\ Sekolah Tinggi Ilmu Administrasi (STIA) - Banten \\ Dini Amalia \\ Sekolah Tinggi Ilmu Ekonomi (STIE) YAI - Jakarta
}

\begin{abstract}
This research focuses on the main problems related to human resources in government agencies, namely how the implementation of training carried out in government agencies so far and how to improve the quality of human resources and career development. This study uses a qualitative method with a phenomenological approach. The data source in this study is primary data obtained from the answers of participants through interviews conducted by 9 staff in 3 government institutions with the aim of gathering information about their experiences in training and how their experiences in career development after going through training. In addition interviews were also conducted with 3 Heads of Human Resources Departments in 3 government institutions to explore how the policy related to training for employees is applied. Based on the results of the analysis, it is known that training and development is necessary to be conducted by the government institutions especially to improve staff performance.
\end{abstract}

Keywords: training and development, staff performance, government institution

\section{Introduction}

Civil servants are laying the foundation of implementing the government system. As stated by Musanef (1996) that the existence of civil servants is essentially the backbone of the government in carrying out national development. Therefore civil servants are expected to be able to mobilize and launch government tasks in development, including serving the public. This opinion was corroborated by Gatot (1992) who stated that civil servants are those who already have the conditions specified in the legislation in force, which are appointed by the competent official, and are entrusted with duties in a public office. In accordance with its main function as the main executor of this country's government, the civil servants are required to have a high work ethic and time discipline. This is certainly a challenge that must be answered by all civil servants in this country, not only in the top ranks, but also in all staff to the lowest level. This is based on the idea that however it cannot be denied, although it is not the only determining factor, the progress of this country depends on the performance of government agencies, in this case the civil servants themselves.

Good and advanced human resources quality will have a positive effect on the agency itself. In order for the institution to progress and be able to provide service excellence, competent and qualified human resources are needed to support the institution's progress. To achieve the quality of human resources, of course, government institutions must hold certain trainings for its staff.

Tamim (2004) argues that one of the attitudes that must be possessed by civil servants is to be able to use and manage time properly in their performance or performance, because time-efficient performance will display the behavior of respecting time. In addition, an employee is also required to be able to compete and be professional in working as a consequence of the increasing demands of their work.

Many complaints come from the public about the performance of civil servants, especially regarding issues related to service. Complaints that often occur are such as delaying the time of service that should be provided to the community immediately without any clear reason. This condition is in accordance with the opinion of Tamim (2004) who revealed that of around four million civil servants spread throughout Indonesia, only $40 \%$ were truly professional, productive, and qualified. Of the total number of civil servants throughout Indonesia, around 24 percent of them were High School graduates. The assessment shows that civil servants are not able to work in teams, lack innovation, and lack motivation. In 2016, the number of civil servants in Indonesia reached 4.37 million people, equivalent to 1.7 percent of Indonesia's population. ${ }^{1}$ To date there are still problems relating to the quality of the civil servants, such as the low competence and level of education of the civil servants, the low number of specialist or functional personnel, and the unequal distribution of expertise.

\footnotetext{
${ }^{1}$ https://beritagar.id/artikel/berita/kualitas-pendidikan-pns-bikin-layanan-birokrasi-kedodoran
} 
Apart from only high school graduates, the majority of civil servants also do not have special expertise. Sixty two percent of civil servants, which is more than half, only have administrative capacity. Therefore, smart and quality staff is an important factor to achieve development goals and to respond to the challenges that will be faced in the future such as the 4th Industrial Revolution and also the Digital Government. However, there is still much that needs to be addressed related to the quality of civil servants in Indonesia, especially in Jakarta as the capital city where all government agencies are centralized here.

Therefore, training for civil servants is needed to upgrade the capabilities of each employee. It is not sufficient if training to be held only once at the beginning of a new employee being hired. Periodical training is required to maintain the stability of employee performance so that it is balanced with future career development. Given the complexity of the problem of human resource quality in government agencies, this paper is intended to answer the following questions:

1. How has the training been implemented in government agencies so far?

2. How to improve the quality of human resources and career development after going through training?

\section{Literature Review}

\section{Training and Development Program}

Development programs worth investing so much into, as most successful organizations consider the progress of workforce and therefore invest in their training. This results to increase in skill and competence that improve morale and productivity (Sheeba, 2011).According to the dynamic developments of all work fields, the organization must develop their HR to strategic HR, because organizations cannot apply a strategic training plan unless they have a strategic human resource management system in place. In the strategic human resource management literature, strategic training is regarded as a vital way of raising employee efficiency (Richard et al., 2009). Chandra (1997) states that management of the organization firmly believes that human assets unlike other asset cannot be depreciated and must necessarily be appreciated over entire tenure. Therefore training is regarded as investment and not a cost. Even long term intangible gains such as attitude change, are to be considered as valuable returns. Training is considered as vehicle for effective communication and coordination. Training is catalytic in any man management matrix for cohesiveness, compatibility, and cooperation in every organizational endeavor.

Training is defined as "a planned process to modify attitude, knowledge, skill or behavior through learning experience to achieve effective performance in an activity or range of activities. Its purpose, in the work situation, is to develop the abilities of the individuals and to satisfy the current and future needs of the organization" (Manpower Services Commission, 1981, p. 62 ). Training is an ongoing planned process that replicates many of the stages involved in the task in order to achieve the intended benefit. Bratton and Gold (2007, p. 197) define Human Resource (HR) planning as 'the process of systematically forecasting the future demand and supply for employees and deployment of their skills within the strategic objectives of the organization'.

According to the Michel Armstrong (2001), training is systematic development of the knowledge, skills and attitudes required by an individual to perform adequately a given task or job. Meanwhile, Edwin B Flippo(1984) says that training is the act of increasing knowledge and skills of an employee for doing a particular job. William Fitzgerald (1992) defines that training as an achievement of the understanding and skill for present the tasks. Next, Goldstein\& Ford, (2002) describe training as a systematic method for learning and development to increase person, team and the organizational efficiency. Continuous training and development of human resource is very crucial and vital because training and development are very important in a world where technological advancement is very rapid and is very important for any organization's success (Laing, 2009). For any organization, training is considered to be of very much importance in order to achieve excellence and competencies (Akhter et al, 2011). Due to weaknesses of vocational training and educational systems in some countries, companies have to increase their budgets for training and development (Hannif and Vo, 2011).

Quality development through training is a major factor determining long term profitability and optimum performance of the organization (Laing, 2009).Mel Kleiman (2000) described that the essentials parts of a worthy employee training program are constructed on orientation, management skills, and operational skills of employees. These theories are the groundwork of any employee development program. Kane (1986) said that if the training and development function is to be effective in the future, it will need to move beyond its concern with techniques and traditional roles. He describes the strategic approaches that the organization can take to training and development, and suggests that the choice of approach should be based on an analysis of the organization's needs, management and staff attitudes and beliefs, and the level of resources that can be committed. This more strategic view-point should be of use in assessing current efforts as well as when planning for the future. 
Regardless of individual differences and whether a trainee is learning a new skill of acquiring knowledge of a given topic, the person should be given opportunity to practice what is being taught. Practice is also essential after the individual has been successfully trained (Sims 1990). The process of training and development is a continuous one. The need to perform one's job efficiently and the need to know how to lead others are sufficient reasons for training and development and the desire to meet organizations objectives of higher productivity, makes it absolutely compulsory (Akinpeju, 1999). According to Swart et al., (2005), bridging the performance gap refers to implementing a relevant training intervention for the sake of developing particular skills and abilities of the employees and enhancing employee performance. According to Wright \&Geroy (2001), employee competencies change through effective training programs. It not only improves the overall performance of the employees to effectively perform the current job but also enhance the knowledge, skills and attitude of the workers necessary for the future job, thus contributing to superior organizational performance.

According to Kenney \& Reid (1986) planned training is the deliberate intervention aimed at achieving the learning necessary for improved job performance. Planned training according to Kenney and Reid consists of the following steps:

Figure 1 The Process of Planned Training

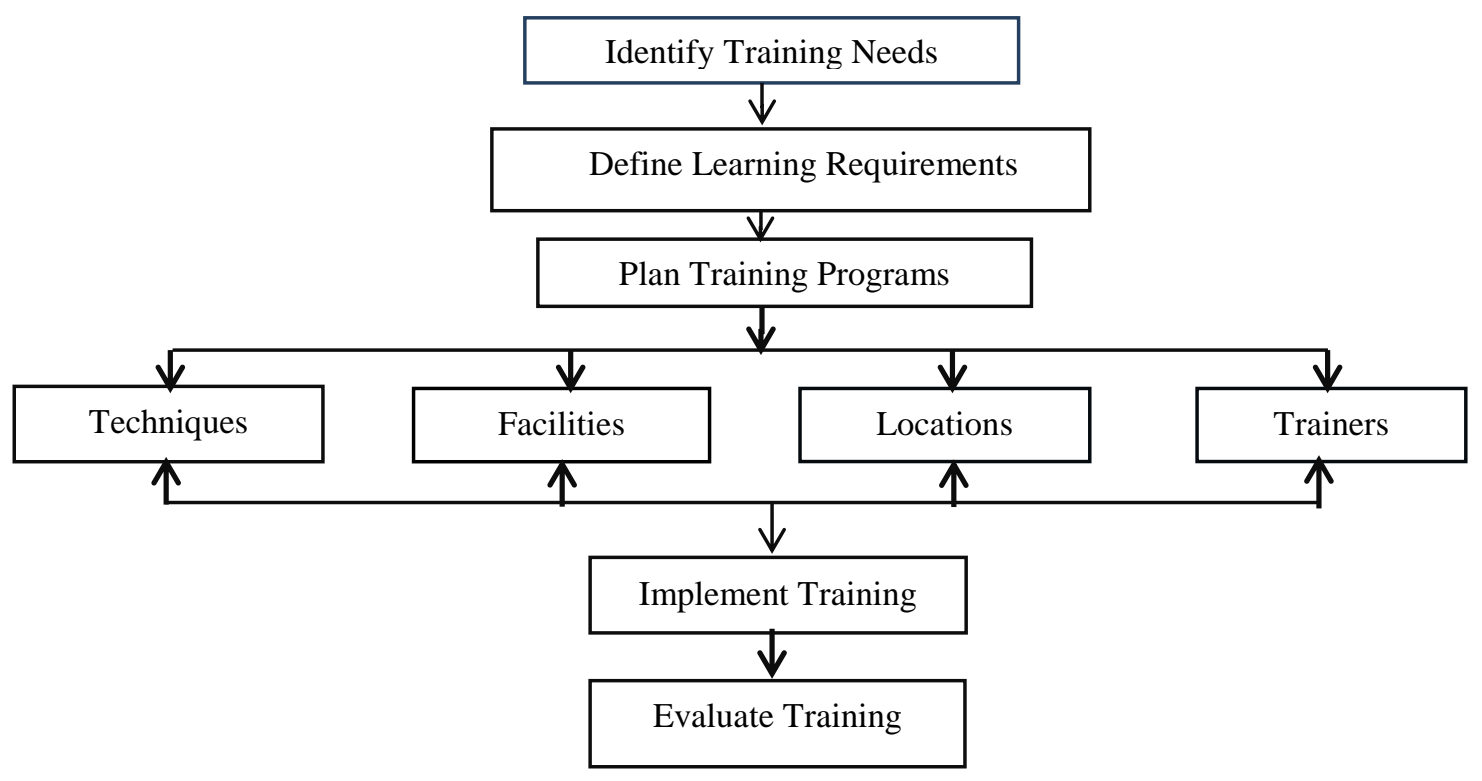

Source: MichaelArmstrong (1995)

\section{Employee Performance}

Performance in the form of task performance comprises of job explicit behaviors which includes fundamental job responsibilities assigned as a part of job description. Task performance requires more cognitive ability and is primarily facilitated through task knowledge (requisite technical knowledge or principles to ensure job performance and having an ability to handle multiple assignments), task skill (application of technical knowledge to accomplish task successfully without much supervision), and task habits (an innate ability to respond to assigned jobs that either facilitate or impede the performance) (Conway, 1999). There is a huge need of career development programs since the new century started and the number of organizations using them has steadily increased since the mid 1970s, as more organizations strive to meet needs of their employees (Merchant, 1995).According to Pfeffer (1998) employee performance can be increased by effective management because human resource has been vital for sustained performance and employee performance is affected by performance management in certain organizations but not in all (Azmi,et.al., 2009).

One of the ways to improve the quality of human resources is through training. Training has been defined as mainly contributing factor to the organizational effectiveness (Schuler and MacMillan 1984). Exploration on this topic recommends that investment in training and development program can be justified by the impact it creates to developed individual and organizational effectiveness (Bartel, 2000). Furthermore, the earlier researches have mentioned causation between training and effectiveness of the organization (Blundell, et.al., 1999). 
Bartlett (2001) recommends that one of the glitches that is usually problematic to identify, is proposing an effective calculation of performance of the organization. Blundell et. al.(1999) supported this by describing that lack of suitable data and methodological difficulties prevents the adequate assessment of impact of human capital appreciation and performance of organization. However, there is an increasing factor that human resource management practices impacts on attitudes and work-related manners (Allen et al., 2003).

To evaluate the effectiveness of training and development program, it has been advised that check directly the relationship of training and organizational commitment. Further it has been revealed as certainly correlated to the efficiency of the organization (Bartlett 2001). According to Lee, et-al, (2011), in a study titled - The effects of internal marketing, job satisfaction and service attitude on job performance among high-tech has always been regarded as an important item in organizational management defined job performance as workers' total performance in meeting the anticipated worth and achievement of tasks under the procedure and time requirements of the organization. Similarly Liao et-al, (2012), define job performance as the standard for advancements, redundancy, rewards, punishments, reviews and salary changes.

Employee performance brings about innovation performance and firm performance as a whole, in such a way that successful effort of fulfilled, inspired, and devoted human resources produce innovative ideas for new products or services and increase quality performance, operative performances, and client satisfaction directly (Sadikoglu and Cemal, 2010).Performance of an employee hence, gives room for innovativeness among employees and general firm's performance and innovativeness, in a manner that prosperous work of accomplished, inspired and zealous human resources yield ground breaking concepts for newer goods or services and also upsurge performance quality and satisfaction of the clients (Sadikoglu \& Cemal, 2010).

According to the results of the study conducted by Yang (2008) on individual performance showed that performance of the individuals cannot be verified. Similarly he asserts that organizations can use direct bonuses and rewards based on individual performance if employee performance is noticeable (Yang, 2008). In line with Yang (2008), Bishop (1987) investigated employee performance and revealed that acknowledgment and recognition and reward of performance of employees direct the discrimination between employee productivity. Moral and productivity of employees is highly influenced by the effectiveness of performance of an organization and its reward management system (Yazic1, 2008).Employee performance is normally looked at in terms of outcomes. However, it can also be looked at in terms of behavior (Armstrong 2000). Kenney (1992) stated that employee's performance is measured against the performance standards set by the organization.

Quality development through training is a major factor determining long term profitability and optimum performance of the organization (Laing, 2009). Employee performance has been increased by training and development which enhances job satisfaction and productivity of the organization (Saleem et.al.,2011). Training and development have positive impact on employee performance (Ghafoor, et.al., 2011) as seen in the following figure.

Figure 2. Training and Development have positive impact on Employee Performance

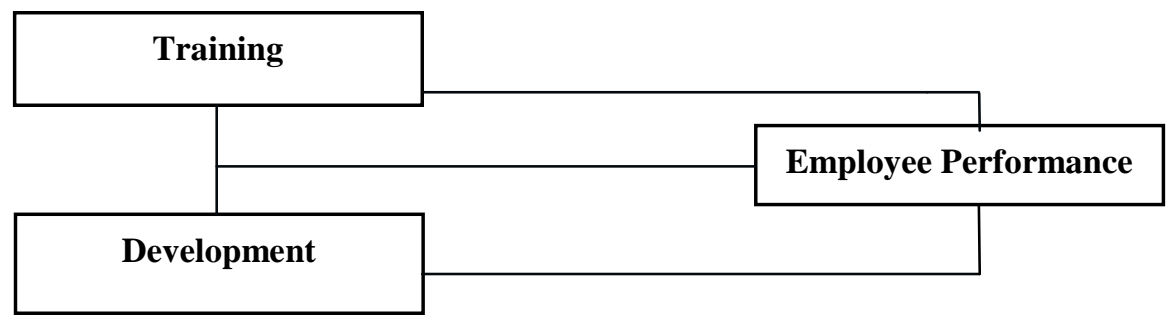

Source :Ghafoor, Ahmed abdAslam (2011)

\section{Research Methods}

In this research, a qualitative research method is employed. The purpose of qualitative research is not formulating general statements but exploring specific social contexts to achieve better understanding of specified social settings ( Patton as quoted in Crabtree \& Miller, 1992 p. 19). That is why the qualitative sample is selected purposefully and case study approach was adopted in this research.

In this research, a phenomenological approach is applied. According to Creswell (2007) a phenomenological study "describes the meaning for several individuals of their lived experiences of a concept or a phenomenon" (p. 57). In other words, it focuses on describing a phenomenon that all the participants have experienced, such as learning a second language in a school system. The purpose of the phenomenological method is to "reduce individual experiences with a phenomenon to a description of the universal essence" (Creswell, 2007, p. 58). 
To achieve this goal, a researcher will usually identify a phenomenon for study. For example, Miller et.al. (2003) identified children who experienced life with diabetes. She then collected data from the children who experienced this phenomenon; and then, described what all the experiences had in common, which is considered the essence of the experiences of this group of children. This description provides "what they have experienced" and "how they experienced it" (Creswell, 2007, p. 58).

The primary and secondary data are required in this study. Data collection takes place through in-depth interviews and multiple interviews (Creswell, 2007). Other forms of data, collected through observation or reviews of journals and art, can be included as well (Creswell, 2007). During an interview, an investigator may ask very general questions. The data were collected by interview, questionnaires and documentation techniques. This study employed semi-structured interviews, because it can direct the interview more closely, to have a pre-determined set of questions while simultaneously allowing the interviewees sufficient flexibility to shape the flow of information given (Wilkinson and Birmingham, 2003). Therefore, the researcher believes that the phenomenological approach is suitable for this research.

Participants for in depth interview consists of 12 people from 3 government institutions namely 9 staff and 3 Heads of Human Resources Departments. The purpose of interviewing staff is to dig deeper the experience they have gained pertaining to training and development in their institutions. Three (3) Heads of Human Resources Departments are important to be interviewed to gain the information related to the needs and types of training they have conducted and how they implement the career development as the post training result.

\section{Research Findings And Discussion}

From the interviews conducted with 3 staff from a government institution, all felt that when they were just accepted to work at an agency, they received training once before starting to work. All employees who have been accepted were trained in the training center. However, the training they received was more general in nature, such as institutional history, corporate culture, institutional policies, and materials related to regulations for employees. Having finished the program, they immediately started working in their respective departments. Of the 3 staff interviewed, all said that this training did not equip new employees with something related to selfmotivation. The training organizers were also taken from internal trainers, namely staff in the Human Resources Department, so the results were not optimal.

"What is needed by new employees is actually more training that can provide motivation and confidence so that we can prepare ourselves before being deployed to a new workplace, because at that time most of those trained were fresh graduates from universities who had no work experience, so to my point of view training on soft skills is more demanded, because the purpose of the training is to improve the quality of self, behavior, attitude, communication as well as skills and knowledge."

This is in accordance with the statement in the Manpower Services Commission (1980, p.62). However, when asked whether regular training is always conducted to improve the capacity and quality of employees, the 3 employees said that employee training was very rarely done in their institutions. If any, those were more related to technical matters, such as the introduction of new technology or new mechanisms as a result of the new policy. The most concerning thing is that the training was held only to carry out programs and obligations as formalities in the HRD department, but after that there was no evaluation of employee competencies so that it did not have an impact on employee career development.

Meanwhile from the interviews with 6 staff from 2 other government institutions, it is found that before they started working, they were given training related more to self development such as Effective Communication, Motivation, Work Ethics, and Career Development, so that fresh graduates can be better prepared to face the workforce. The training organizers are also chosen from the professional training institutions so that they gain not only new knowledge but also exciting new experiences. These employees also said that after the training was held, other training sessions were held regularly, at least every 6 months. The training module is adjusted to their field of work, so that it is more specific and technical.

" The institution where I am working always organizes training for employees on a regular basis in collaboration with professional training institutions. Employee skills and competencies are also perceived to be increasing. In my opinion, the role of HRD is very big in determining the training institutions to be sub-contracted, not only in terms of modules and learning methods but also professional trainers make the training more exciting and fun. This has a very good impact on the competencies achieved by trainees. "

This is in accordance with the statements of Akhter, Ali, Sadaqat and Hafeez (2011) who said that for any organization, training is considered to be of very much importance in order to achieve excellence and competencies.In addition, an important aspect of training is employee career evaluation and development. 
From the interviews with 6 staff in 2 government agencies, it was found that evaluation and career development were very well implemented. Every employee who has participated in the training was given assistance so that he or she could properly implement the skills and knowledge had gained from the training. The HRD department also periodically evaluates employee performance.

"The training organized by the HRD department is indeed motivates employees to work better. In addition, HRD always conducts evaluation and performance appraisal to see the progress of the employees and those who excel and able to show good achievements will be rewarded in the form of various types of prizes as well as promotion. "

This is in accordance with the statement of Swart et al., (2005) that bridging the performance gap refers to implementing a relevant training intervention for the sake of developing particular skills and abilities of the employees and enhancing employee performance.

Interviews were also conducted with 3 Heads of Human Resources Departments to find out how their perspectives were related to training for employees, as well as how they conducted training programs in their respective institutions. Of the 3 people interviewed, only one said that the training carried out at agencies was held more internally, with internal trainers from HRD staff and internal officials as well. This is due to the limited budget allocated for employee training. "If you have to invite training institutions from outside the office, you will certainly need a significant amount of budget." From the answers given, it can be concluded that not all agencies understand that employee training is an investment and should not be considered as a 'cost' or a burden on agencies as stated by Chandra (1997).

However, the interviews with staff also show the data that there are still many aspects need to be improved, namely:

1. The implementation of training which is often less effective, because training is generally carried out in the office so that many employees are late entering the classroom because they have to solve problems in their department. The training should be held outside the office or outside the city, so that each employee can focus on joining the program until completion.

2. Training held in agencies is mostly related to technical matters or hard skills and HRD very rarely provides training related to soft skills, even though soft skills are really needed by all employees in order to maintain their performance continuously.

3. Government agencies should cooperate with professional institutions with good track records in organizing training, so that the program runs as expected with optimal results.

4. Competencies achieved by employees from training must be accompanied by career development so that the training program does not become a waste.

Meanwhile, the authors' interviews with the Head of Human Resources in 3 government offices show that in the current global era, employee training has become a demand in all government institutions, given the very rapid changes and increasingly sophisticated technology, if not followed by the quality of human resources, then Indonesia will be far behind those of its neighbors.

"The most important thing before we determine what type of training will be held, the HRD section always has to do a need analysis related to employee training. This is important so that the training we hold is right on target. After that we also have to determine where the training location is. Based on experience, training held at the office is indeed less effective because many participants have to leave the training room and finish their work. It is different if the training is conducted out of town, the results are far more effective. Related to the methodology (technique) applied and the trainers, we cooperate more frequently with professional training institutions which are experienced and have a good track record. This is very important because it influences its output and is in accordance with the Government Regulation of the Republic of Indonesia Number 31 of 2006 concerning the National Training System which states that the training institutions are government agencies, or legal entities or individuals who meet the requirements to organize training. "

This statement is in accordance with the concept of Michael Armstrong (1995). In addition, all employees who are trained should be given the opportunity to practice what is being taught. Practice is also essential after the individual has been successfully trained (Sims, 1990). When confronted about budget issues for employee training, not all of them understand that the costs incurred for employee training are actually an investment for the institution. There are still institutions that assume that the cost of training employees is a burden on companies so that their use must be tightened. This is not in accordance with the opinion of Sheeba (2011) which states that development programs are worth investing so much into, as the most successful organizations, consider the progress of workforce and therefore invest in their training. Meanwhile related to the evaluation and career development of employees after attending the training, the three Heads of HRD said that until now the most difficult thing faced was the placement of employees according to their expertise. This is caused by the large number of employees in government agencies that are not in accordance with the existing position. 
Therefore HRD in government agencies are always judged to be too slow in handling issues related to employee promotions. Nevertheless, HRD in government institutions must be selective in determining the position of an employee in accordance with their competencies.

\section{Conclusion}

From the above analysis it can be concluded that training and development is very important and has a large role in improving employee performance. However, the training program carried out at government agencies in Jakarta has not been fully implemented as expected. There are still agencies that consider that training costs are a burden rather than investment for the institution. This mindset must be changed so that government agencies can improve the quality of their human resources to be more professional. For future research researchers can discuss in more detail related to training evaluation with different approaches.

\section{References}

Akhtar, Ali, Sadaqat and Hafeez.(2011). Extent of Training in Banks and Its Impact on Employee Motivation and Involvement in Job.Interdisciplinary Journal of Contemporary Research Business Vol. 2 No 12.

Akinpeju. (1999). A Literature Review On Training \& Development. Journal of Arts, Science\& Commerce.

Allen, David, RodgerGriffeth, Lynn M.Shore.(2003). The Role of Perceived Organizational Support and Supportive Human Resource Practices in the Turnover Process. Journal of Management 29(1):99-118 - January 2003. DOI: $10.1177 / 014920630302900107$.

Armstrong, Michael. (2000). "Understanding Training". Human Resource Management Practice. 8th Edition. Kogan page limited, London. pp:543

Armstrong, M. (2006). A Handbook of Human Resource Management Practice, London, UK:Kogan Page, Ltd.

Azmi,Zainal Ariffin Ahmad, Yuserrie Zainuddin .(2009). Competency-Based Pay And Service Quality: An Empirical Study Of Malaysian Public Organisations. Semantic Scholar. Https://Www.Semanticscholar.Org/Paper/COMPETENCY-BASED-PAY-AND-SERVICE-QUALITY\%3AAN-STUDY-Azmi-Ahmad/C55d5851a5f81b40e4463d5eebd85eeade818e0b

Bartel, A.P. (2000). Measuring the Employer's Return on Investment in Training: Evidence from the Literature.Industrial Relations,39, 3, 502-524.

Bartlett, K.R. (2001). The Relationship between Training and Organizational Commitment: A Study in theHealth Care Field. Human Resource Development Quarterly, 12, 4, 335-352.

Bishop.J. (1987). The Recognition and Reward of Employee Performance.Journal of Labor Economics, 1987, vol. 5, issue 4, S36-56. Copyright 1987 by University of Chicago Press.

Blundell, R., Dearden, L., Meghir, C. and Sianesi, B. (1999). Human Capital Investment: The Returns from Education and Training to the Individual, the Firm and the Economy. Fiscal Studies, 20(1): 1-23.

Bratton, J., \& Gold, J. (Eds.). (2007). Human resources management theory and practice (4th Edition ed.). Macmillan: Houndmills.pp 197.

Chandra. (1997).Alternatives Approaches and Strategies of Human Resource Development, Rawat Publications . pp 2-3.

Conway, J. M. (1999).Distinguishing contextual performance from task performance for managerial jobs.Journal of Applied Psychology, 84, 3-13.

Creswell, J. (2007). Qualitative Inquiry \& Research Design: Choosing Among. Five Approaches, 2 nd ed. California : Sage Publication.

Edwin B. Flippo (1984). Personnel Management, McGraw Hill; $6^{\text {th }}$ Edition, 1984.

FengHui Lee, WannYih Wu, Tsai Zang Lee. (2011). The relationship between human resource management practices, business strategy and firm performance: Evidence from steel industry in Taiwan. The International Journal of Human Resource Management 21(9):1351-1372 · July 2010. DOI: 10.1080/09585192.2010.488428

Fitzgerald, William.(1992). Training versus Development.Questia Trusted Online Research. Magazine Article Training and Development.

Gatot, I. (1992). HimpunanLengkap UU dan PP Kepegawaian Negara.Jilid 1.Bandung : PT. Karya Nusantara.

GhafoorRaja Abdul Khan, Furqan Ahmed Khan, Dr. Muhammad Aslam Khan. (2011). Impact of Training and Development on Organizational Performance By University of Lahore, Islamabad Pakistan. Global Journal of Management and Business Research Volume 11 Issue 7 Version 1.0 July 2011

Goldstein, I. L., \& Ford, J. K. (2002).Training in organizations Needs Assessment, Development, and Evaluation (4th ed.). Belmont, CA Wadsworth 
Hannif, Z. Nadiyah. \&Vo, A. (2011). Call centre job functions and the quality of work life: revisiting the job characteristics model. International Journal of Business Research, 11 (2), 236-247.

Kane.R.L. (1986). A Strategic Look at Training and Development.Asia Pacific Journal of Human Resources.Willey Online Library. https://onlinelibrary.wiley.com/doi/abs/10.1177/103841118602400313

Kenney, J. \& Reid, M. (1986). Training Interventions. London: Institute of Personnel Management.

Kenney, E. (1992). Management Made Easy. 1st ed. South Carolina: Omron Publishers.

Kleiman, Mel. (2000). What happens if you don't train them and they stay? Occupational Health and Safety, January, 69 (1), pp. 18, 70.

Laing. (2009).Impact Of Training and Development on Employee Performance.Institute of Distance Learning-KNUST.

Liao, C. W., Lu, C. Y., Huang, C. K., \& Chiang, T. L. (2012). Work values, work attitude and job performance of green energy industry employees in Taiwan. African Journal of Business Management, 6(15), 5299-5318

Manpower Services Commission.1981. The New Training Initiative, Sheffield: MSC

Merchant, Robert, C. (1995).The Role of Career Development in Improving Organizational Effectiveness and Employee Development.Bartleby Research.

https://www.bartleby.com/essay/The-Role-of-Career-Development-in-Improving-FKZ28ZE36YYS

Michael Armstrong.(2001).A Handbook of Human Resource Management Practice.Kogan Page, 8th Ed.

Miller, Gregory.E, Edith Chen, Karen J Parker . (2003). Psychological Stress in Childhood and Susceptibility to the Chronic Diseases of Aging: Moving Towards a Model of Behavioral and Biological Mechanisms. https://www.ncbi.nlm.nih.gov/pmc/articles/PMC3202072/

Musanef .(1996). ManajemenKepegawaian di Indonesia. Jakarta: GunungAgung.

Patton, M.Q. (1990). Qualitative evaluation and research methods (2nd ed.). Newbury Park, CA: Sage, 532 pp.

Peraturan Pemerintah Republik Indonesia Nomor 31 Tahun 2006 Tentang Sistem Pelatihan Kerja Nasional. Jakarta: KementerianTenagaKerjaRepublik Indonesia.

Pfeffer, J. (1998). The human equation Building Profits by Putting People First. Boston: Harvard Business School Press.

Pierre J,Richard, Timothy M. Devinney, George.S.Yip and Gerry Johnson. (2009). Measuring Organizational Performance: Towards Methodological Best Practice. Journal of Management 35 (3). June 2009. DOI: 10.1177/0149206308330560. http://jom.sagepub.com.

Sadikoglu, E., \&Zehir, C. (2010). Investigating the effects of innovation and employee performance on the relationship between total quality management practices and firm performance: An empirical study of Turkish firms. International Journal of Production Economics, 127(1), 13-26.

Saleem. Shahid and Naseem (2011), „Degree of Influence of Training and Development on Employee Behaviour ${ }^{\text {,e }}$ International Journal of Computing and Business Research ISSN (Online) : 2229-6166 Vol. 2

Schuler, Randall.S, Ian. C. MacMillan. (1984).Gaining competitive advantage through human resource managementpractices. Willey Online Library.First published: Autumn (Fall) 1984 https://doi.org/10.1002/hrm.3930230304

Sheeba Hamid (2011): "A Study of Effectiveness of Training and Development Programmes of UPSTDC, India - An analysis", South Asian Journal of Tourism and Heritage, Vol.4 (1).

Sims, R. (1990). An Experiential Learning Approach to Employee Training Systems. New York:Quorum Books.

Swart, J., Mann, C., Brown, S. \& Price, A. 2005. Human Resource Development: Strategy and Tactics. Oxford.

Elsevier Butterworth-Heinemann Publications.

Tamim, Faisal.(2004).Reformasi Birokrasi : Analisis Pemberdayaan Aparatur Negara, Jakarta : Belantika.

Wilkinson, David \& Birmingham, Peter. (2003). Using Research Instruments: A Guide for Researchers. Routledge Study Guides. ISBN 0415272793.

Wright, P. \&Geroy, D. G. (2001). Changing the mindset: the training myth and the need for word-class performance. International Journal of Human Resource Management 12,4, 586-600.

Yang, H. (2008).Efficiency Wages and Subjective Performance Pay.Economic Inquiry, 46(2), pp. 179-196.

Yazıc1, N. K.. (2008). The Effect of Reward System Applications on Employee Performance In Service Sector. Marmara University, Institute of Social Sciences.Master Thesis.

Websites:

https://beritagar.id/artikel/berita/kualitas-pendidikan-pns-bikin-layanan-birokrasi-kedodoran https://www.liputan6.com/bisnis/read/3653839/kepala-bappenas-ungkap-kondisi-dan-kualitas-pns-saatini?related=dable\&utm_expid=.9Z4i5ypGQeGiS7w9arwTvQ.1\&utm_referrer=https\%3A\%2F\%2Fwww.google.com\% $2 \mathrm{~F}$ 